\title{
Kualitas Kimia Asap Cair Ranting Cengkeh
}

\author{
${ }^{1}$ Yusnaini dan ${ }^{2}$ Asrul Dedy \\ ${ }^{1}$ Program Studi Peternakan, Fakultas Pertanian, Universitas Khairun, Jl Raya Gambesi Ternate \\ ${ }^{2}$ Program Studi Agroteknologi, Fakultas Pertanian, Universitas Khairun, Jl Raya Gambesi Ternate \\ e-mail: ${ }^{1}$ yusnaini_unkhair@yahoo.co.id, ${ }^{2}$ dedyasrul_67@yahoo.com
}

\begin{abstract}
Abstrak. Bahan baku produksi asap cair yang terpilih pada penelitian sebelumnya adalah ranting cengkeh. Penelitian tentang penggunaan ranting cengkeh masih sangat kurang sehingga produksi asap cair dari ranting cengkeh ini belum diketahui kualitasnya baik asap cair kasar maupun setelah dimurnikan. Begitupula dengan konsentrasi yang efektif digunakan sebagai bahan pengawet pada pangan. Penelitian ini bertujuan untuk mengetahui kualitas asap cair kasar dan asap cair yang telah dimurnikan dan mengevaluasi konsentrasi asap cair yang akan diaplikasi pada bahan pangan. Produksi asap cair dilakukan dengan suhu pirolisis $420^{\circ} \mathrm{C}$ selama 100 menit dan dilakukan pengukuran volume asap cair. Asap cair kasar kemudian didestilasi pada suhu $100{ }^{\circ} \mathrm{C}$ selamal jam, kemudian dilakukan pengenceran dengan konsentrasi 5\%, 10\%, 15\% dan 20\%. Dilakukan analisis kualitas antara lain kadar fenol, karbonil dan asam. Hasil penelitian yang diperoleh adalah rendemen asap cair kasar yang dihasilkan sekitar 36,44\% dan yang setelah pemurnian 19,96\%. Proses pemurnian menyebabkan penurunan kadar fenol, karbonil dan asam yaitu secara berturut-turut sekitar 93-96\%; 31-46\%; dan 6064\%. Pengenceran asap cair mempengaruhi kadar fenol, karbonil dan asam asap cair. Makin tinggi konsentrasi asap cair maka persentase kadar senyawa fenol, karbonil dan asam makin tinggi pula. Kesimpulan penelitian ini adalah asap cair yang diproduksi dari ranting cengkeh dapat digunakan sebagai pengawet bahan pangan dan aplikasinya pada pangan dengan konsentrasi $10 \%$.
\end{abstract}

Kata kunci : rendemen, kualitas kimia, asap cair, ranting cengkeh

\section{Pendahuluan}

Penggunaan asap cair sebagai pengganti pengasapan tradisional mulai dikembangkan pada akhir tahun 1980 (Pszczola, 1995). Perkembangan produksi dan penggunaan asap cair pada pangan sangat pesat, hal ini dapat dilihat banyaknya penelitian produksi asap cair dari berbagai macam bahan baku anatara lain tempurung kelapa (Tranggono et al., 1996; Yusnaini dan Indah Rodianawati, 2014), Vitis venivera L. (Guillen dan Ibargoitia, 1996), berbagai macam limbah pertanian (Darmadji, 1996), Fagus sylvatica L. (Guillen dan Ibargoitia, 1999), limbah padat rempah (Darmadji et al., 1999), kayu Karet (Darmadji et al., 2000), tempurung biji pala (Yusnaini dan Indah Rodianawati, 2014), tempurung kelapa hibrida (Kadir et al., 2010) dan tempurung kenari (Yusnaini, 2012; Yusnaini dan Indah Rodianawati, 2014), serbuk gergaji, batang mangrove, ranting cengkeh, ranting pala, batang pohon kelapa, batang kenari (Yusnaini dan Indah Rodianawati, 2014). 
Asap cair dapat berfungsi sebagai bahan pengawet dan dapat mengganti pengawet kimia yang beredar di pasaran. Pengawetan makanan yang diasapi merupakan kerja senyawa yang terdapat dalam asap cair terutama senyawa aldehid, asam organik molekul rendah dan fenol (Luck dan Jager, 1995). Asap cair mengandung komponen senyawa fenol dan asam organik yang menghambat pertumbuhan mikroorganisme pembusuk dan patogen (Estrada et al., 1998). Ketahanan bakteri patogen dan pembusuk terhadap perlakuan asap berbeda (Girard, 1992).

Provinsi Maluku Utara juga merupakan provinsi kepulauan dengan sumber daya perikanan dan pertanian yang berlimpah. Hasil tangkapan dan produksi pertanian memerlukan pengawet yang aman terutama pada saat produksi banyak. Asap cair merupakan bahan pengawet alami sehingga dapat digunakan sebagai bahan pengawet alternatif bagi pangan. Bahan baku yang digunakan untuk produksi asap cair adalah ranting cengkeh. Hal ini berdasarkan hasil penelitian Yusnaini dan Indah Rodianawati (2014) bahwa rendemen dan kualitas kimia asap cair maka penggunaan bahan baku ranting cengkeh untuk produksi asap cair lebih unggul. Penelitian tentang aplikasi asap cair ranting cengkeh pada pangan masih sangat kurang sehingga perlu dilakukan penelitian lebih lanjut tentang kualitas asap cair ranting cengkeh dan evaluasi konsentrasi yang efektif untuk aplikasi pada bahan pangan. Tujuan penelitian ini adalah untuk mengetahui kualitas asap cair kasar dan asap cair yang telah dimurnikan dan mengevaluasi konsentrasi asap cair yang akan diaplikasi pada bahan pangan.

\section{Metode Penelitian}

\subsection{Produksi Asap Cair}

Bahan baku yang digunakan untuk produksi asap cair adalah ranting cengkeh yang diambil di Kelurahan Gambesi Kecamatan Ternate Utara Provonsi Maluku Utara. Pembuatan asap cair dilakukan dengan cara pirolisis. Tungku pirolisis dilengkapi dengan pemanas listrik 1500 watt yang melingkari reaktor pirolisis yang berdiameter 20 $\mathrm{cm}$ dengan tinggi $40 \mathrm{~cm}$ diisi $4 \mathrm{~kg}$ bahan baku. Pirolisis dilakukan pada suhu $420^{\circ} \mathrm{C}$ selama 100 menit (Darmadji et al., 2000). Embunan berupa asap cair yang masih tercampur dengan tar ditampung dalam tabung erlenmeyer, selanjutnya disimpan. Asap yang tidak terembunkan akan terbuang melalui selang penyalur asap cair. Setelah itu dilakukan pengukuran volume asap cair dan tar. Selanjutnya dilakukan pemurnian asap cair. Pemurnian dilakukan dengan cara destilasi asap cair kasar pada suhu $100^{\circ} \mathrm{C}$.

Rendemen ditentukan dengan rumus sebagai berikut :

Rendemen $(\% \mathrm{~b} / \mathrm{b})=\frac{\text { Rendemen asap cair }}{\text { Bobot bahan baku }}$




\subsection{Uji Kualitas Asap Cair}

\section{a. Analisa Fenol (AOAC, 1990)}

Ditimbang 0,5 - 0,6 g contoh ditambahkan $30 \mathrm{~mL}$ aquades, lalu dimasukkan ke dalam labu ukur $250 \mathrm{~mL}$. Kemudian ditambahkan $5 \mathrm{~mL}$ larutan $\mathrm{NaOH} \mathrm{0,2} \mathrm{N}$ dan diencerkan dengan aquades sampai tanda tera. Dari larutan tersebut dipipet sebanyak 25 $\mathrm{mL}$ dan dimasukkan dalam erlenmeyer ukuran $300 \mathrm{~mL}$, lalu ditambahkan Bromat Bromida 0,2 N; 50 mL aquades; 5 mL HCL pekat (digoyang selama 1 menit) kemudian di tambahkan $5 \mathrm{~mL}$ Kalium iodida $15 \%$ (digoyang kembali selama 1 menit), ditambahkan lagi 5 tetes amilum (sebagai indikator) dan digoyang lagi selama 1 menit, selanjutnya di titrasi dengan Natrium thiosulfat $\left(\mathrm{Na}_{2} \mathrm{SO}_{3}\right) \quad 0,1 \mathrm{~N}$.

Kadar fenol $=$ Y

(mL titer blanko $-\mathrm{mL}$ titer contoh) $\mathrm{x} \mathrm{BM}$ fenol/6 $\times 1.000$

$\mathrm{Y}=$

$$
0,1 \times \text { bobot contoh }(\mathrm{g})
$$

\section{b. Analisa Total Asam (AOAC, 1990)}

Sebanyak $5 \mathrm{~mL}$ asap cair ditambahkan $100 \mathrm{~mL}$ aquades, lalu di kocok sampai homogen kemudian tambahkan 3 tetes indikator pp. Selanjutnya dititrasi dengan $\mathrm{NaOH}$ 0,1 N sampai berwarna merah muda. Total asam yang terukur dianggap sebagai asam asetat. Kadar Asam Asetat $=$ Y

$$
\mathrm{Y}=\frac{\text { Jumlah } \mathrm{mL} \text { titer } \mathrm{x} \text { Normalitet } \mathrm{NaOH} \text { x } 60}{\mathrm{-} \text { Volume contoh }(\mathrm{mL}) \times 1.000}
$$

\section{c. Analisa Karbonil}

Analisa karbonil asap cair menggunakan spektrometer 21D UV-160 metoda colormetrik.

\subsection{Analisis Data}

Data kualitas kimi asap cair kasar dianalisis secara deskriktif dam data asap cair setelah pemurnian yang diperoleh selanjutnya dianalisis statistik dengan menggunakan Software Statistical Product and Service Solution (SPPS) versi 16 dengan metode One Way Anova dengan signifikan 5\% dan apabila terdapat perbedaan yang nyata dilanjutkan dengan uji Duncan pada taraf $\alpha=5 \%$.

\section{Hasil Dan Pembahasan}

\subsection{Rendemen}

Rendemen asap cair kasar dan setelah pemurnian setelah pirolisis $1 \mathrm{~kg}$ ranting cengkeh dapat dilihat pada Tabel 1. 
Tabel 1: Rendemen Asap Cair Kasar dan Setelah Pemurnian

\begin{tabular}{cccccc}
\hline \multirow{2}{*}{ Pirolisis } & Sampel (g) & \multicolumn{2}{c}{ Asap Cair Kasar } & \multicolumn{2}{c}{$\begin{array}{c}\text { Asap Cair Setelah } \\
\text { Pemurnian }\end{array}$} \\
\cline { 3 - 6 } & & ml & \% & ml & \% \\
\hline 1 & 1.000 & 366 & 36,60 & 268 & 26,80 \\
2 & 1.000 & 362 & 36,20 & 188 & 18,80 \\
3 & 1.000 & 366 & 36,60 & 209 & 20,90 \\
4 & 1.000 & 357 & 35,70 & 148 & 14,80 \\
5 & 1.000 & 371 & 37,10 & 185 & 18,50 \\
\hline Jumlah & & $\mathbf{1 , 8 2 2}$ & $\mathbf{1 8 2}$ & $\mathbf{9 9 8}$ & $\mathbf{1 0 0}$ \\
\hline Rata-Rata & & $\mathbf{3 6 4 , 4 0}$ & $\mathbf{3 6 , 4 4}$ & $\mathbf{1 9 9 , 6 0}$ & $\mathbf{1 9 , 9 6}$ \\
\hline
\end{tabular}

Berdasarkan Tabel 1 diatas dapat dilhat bahwa rendemen asap cair kasar yang dihasilkan sekitar 36,44\% dan yang setelah pemurnian $19.96 \%$. Hasil penelitian ini berbeda dengan hasil penelitian Yusnaini dan Indah Rodianawati (2014) bahwa rendemen asap cair kasar dari ranting cengkeh sekitar 46.5\%. Rendemen asap cair dari tempurung kenari berturut-turut adalah $42,58 \%$ (Yusnaini et al., 2013). Rendemen asap cair tersebut hampir sama dengan rendemen asap cair tempurung kelapa hibrida sekitar 42,62\% (Kadir et al., 2010), namun lebih rendah dari hasil penelitian Tranggono et al. (1996) dengan bahan baku tempurung kelapa menghasilkan rendemen sekitar 52,85\%.

\subsection{Kualitas Kimia Asap Cair Ranting Cengkeh}

Kualitas kimia asap cair kasar dapat dilihat pada Gambar 1 dan setelah pemurnian pada Gambar 2.

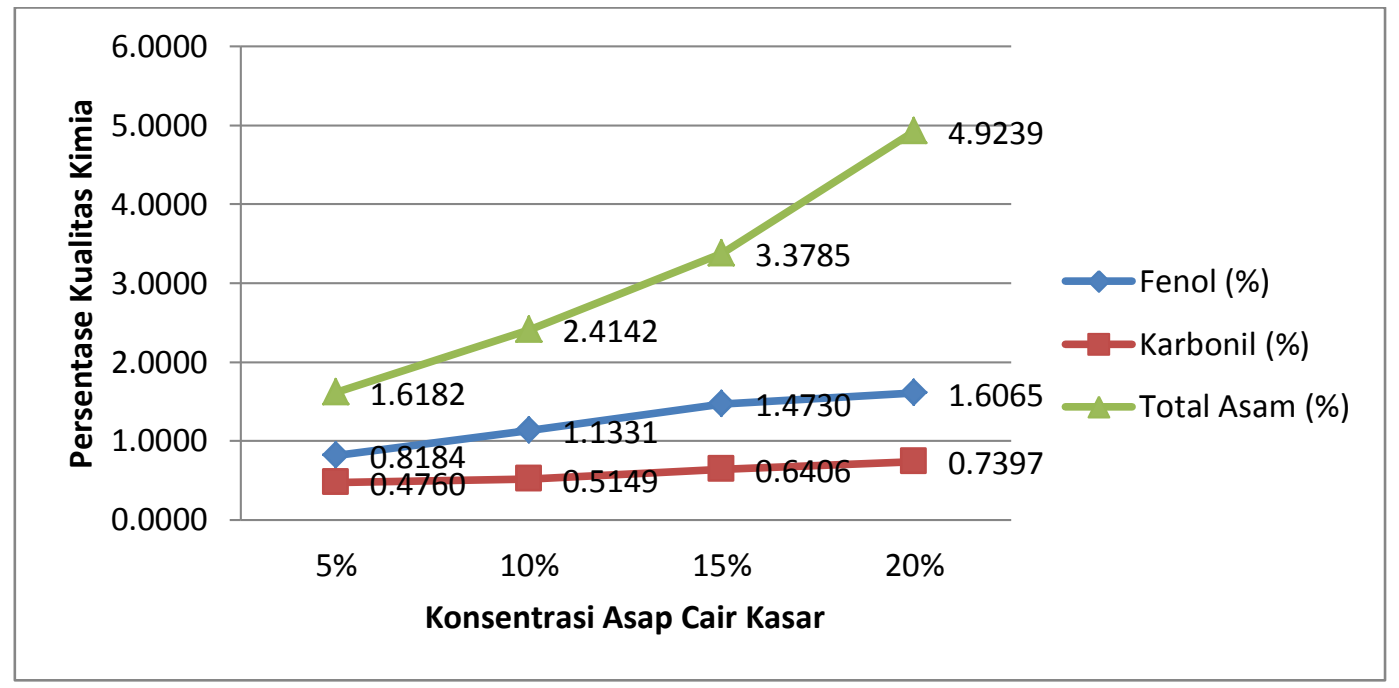

Gambar 1: Kualitas Kimia Asap Cair Kasar dari Ranting Cengkeh

Kualiatas kimia asap cair kasar dari bahan baku ranting cengkeh pada Gambar 1 menunjukkan bahwa makin tinggi konsentrasi asap cair maka makin tinggi pulan kadar senyawa fenol, karbonil dan asam acap cair kasar tersebut. 
Pirolisis merupakan proses pemecahan lignoselulosa oleh panas dengan oksigen yang terbatas dan menghasilkan gas, cairan dan arang yang jumlahnya tergantung pada jenis bahan, metode dan kondisi pirolisis (Girard, 1992). Selanjutnya dijelaskan bahwa tiga unsur utama kayu adalah selulosa, hemiselulosa, dan lignin. Proporsi tiga polimer struktural ini bervariasi pada setiap tipe kayu, namun secara kasar dalam rasio 2 bagian selulosa, 1 bagian lignin, dan 1 hemiselulosa. Komponen kayu yang pertama kali mengalami dekomposisi adalah hemiselulosa, dengan komponen penyusun glukosa, mannosa, galaktosa, xilosa, arabinosa, rhamnosa, 4-O-metil-asam galakturonat dan asam galakturonat (Maga, 1988). Pirolisis hemiselulosa mengarah ke formasi furfural, furan, dan derivat-derivatnya bersama dengan suatu seri panjang asam karboksil (Girard, 1992). Hal ini sejalan dengan pernyataan Maga (1987) bahwa hemiselulosa menghasilkan furfural (2-furankarboksaldehid), furan dan asam karboksilat serta tar pada proses pirolisis dengan suhu yang tinggi.

Komposisi kimia asap cair tempurung biji nyamplung pada suhu $300^{\circ} \mathrm{C}$ teridentifikasi 42 komponen dan komponen yang dominan adalah asam asetat $(29,83 \%), 350^{\circ} \mathrm{C}$ teridentifikasi 42 komponen dan komponen yang dominan adalah asam asetat $(21,42 \%)$ dan $400^{\circ} \mathrm{C}$ teridentifikasi 48 komponen dan komponen yang dominan adalah asam asetat (24,34\%) (menggunakan GC-MS) (Indah Rodianawati, 2012). Kadar fenol, karbonil dan asam asap cair tempurung kenari sebelum destilasi masing - masing 10,746 - 13,506\%; 34,167 - 45,625 dan 12,380 - 13,482 dan setelah destilasi berkisar 1,720 - 3,821\%; 27,656 - 30,911 dan 8,366 - 9,430\% (Yusnaini, 2009).

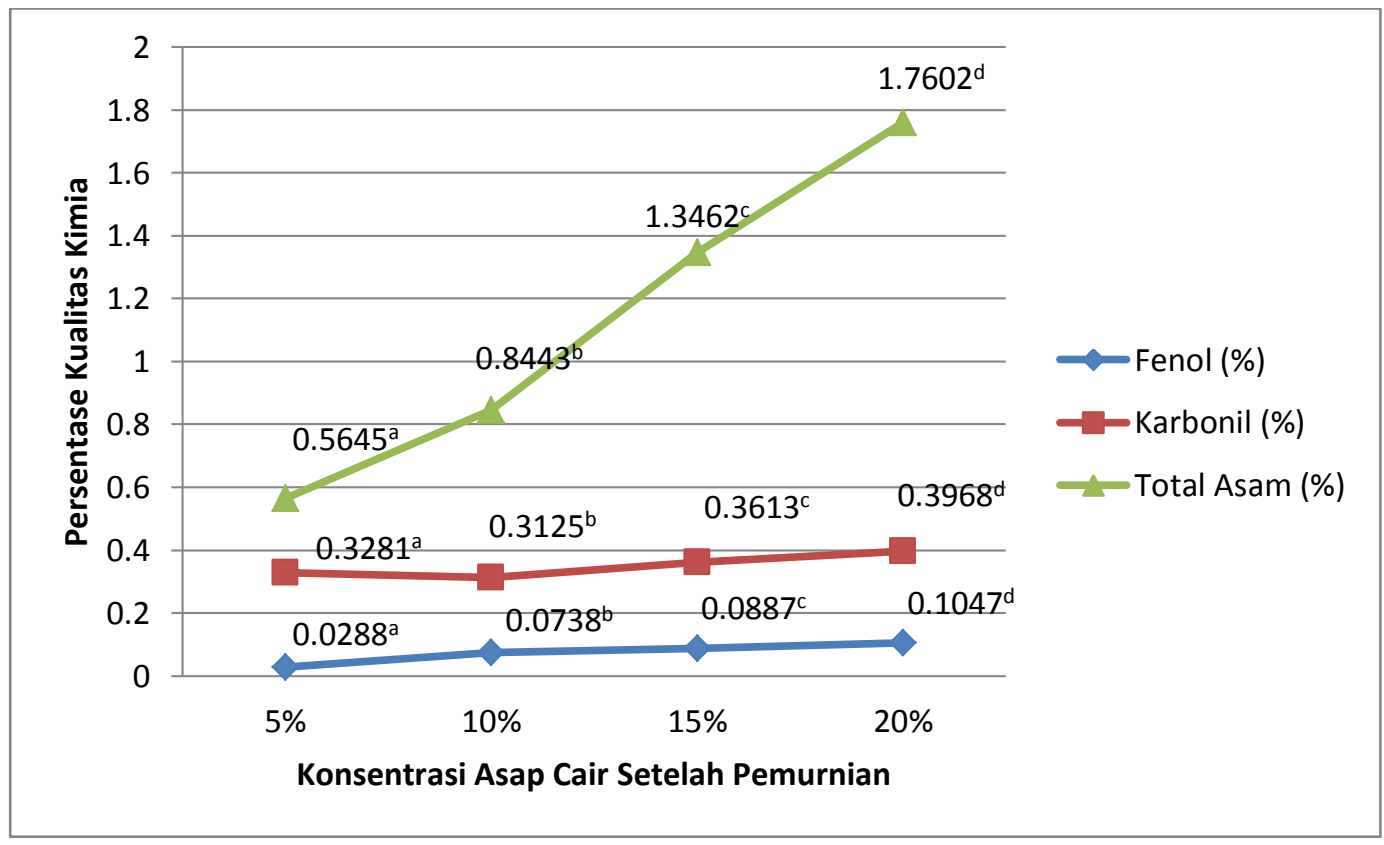

\section{Gambar 2. Kualitas Kimia Asap Cair Setelah Pemurnian dari Ranting Cengkeh}

Pada Gambar 2 diatas menunjukkan bahwa makin tinggi konsentrasi asap cair maka makin tinggi pula kadar senyawa fenol, karbonil dan asam asap cair. Jika dibandingkan dengan kualitas kimia asap cair kasar pada Gambar 1 maka diperoleh bahwa terjadi penurunan kadar senyawa fenol, karbonil dan asam setelah proses 
pemurnian dengan destilasi. Penurunan yang peroleh adalah senyawa fenol sekitar 9396\%, senyawa karbonil sekitar 31-46\% dan senyawa asam sekitar 60-64\%.

Hasil analisis sidik ragam menunjukkan bahwa konsentrasi asap cair berpengaruh nyata $(\mathrm{P}<0,05)$ terhadap kadar fenol, karbonil dan asam asap cair. Setelah dilakukan uji lanjut diperoleh hasil bahwa setiap konsentrasi asap cair berbeda nyata $(\mathrm{P}<0,05)$ dengan konsentrasi asap cair lainnya. Hal ini berarti perbedaan konsentrasi asap cair mempunyai kadar fenol, karbonil dan asam yang berbeda pula.

Asap cair ranting cengkeh ini akan diapalikasi sebagai bahan pengawet pada bahan pengan sehingga perlu evaluasi lebih lanjut konsentrasi asap cair ranting cengkeh yang akan digunakan. Senyawa yang berfungsi sebagai bahan pengawet adalah fenol dan asam. Konstituen pengawetan makanan yang diasapi terutama adalah aksi aldehid, asam organik molekul rendah dan fenol (Luck dan Jager, 1995). Asap cair mengandung komponen fenol dan asam organik yang menghambat pertumbuhan mikroorganisme pembusuk dan patogen (Estrada et al., 1998). Ketahanan bakteri patogen dan pembusuk terhadap perlakuan asap berbeda (Girard, 1992). Senyawa fenol berperan sebagai donor hidrogen dan efektif dalam jumlah kecil untuk menghambat terjadinya oksidasi pada lemak atau mencegah terjadinya oksidasi lipid dengan menstabilkan radikal bebas dan efektif untuk mencegah terjadinya off flavor (Pszczols, 1995).

Kadar fenol dan asam yang diperoleh berbeda nyata $(\mathrm{P}<0,05)$ pada masingmasing konsentrasi. Namun penggunakaan asap cair sebagai bahan pengawet diharapkan lebih efisien dan dapat digunakan pada bahan pangan yang lebih banyak. Pada kadar fenol dapat dilihat terjadi kecenderungan penurunan yang tajam pada konsentrasi 5\% sehinggan untuk aplikasi pada pangan akan digunakan asap cair dengan konsentrasi $10 \%$. Aktifitas antibakteri asap cair efektif pada konsentrasi tinggi, tetapi pada pengenceran 10 kali aktifitas penghambatan semakin menurun (Darmadji et al., 1996). Kusharyati (1998) menyatakan bahwa penggunaan asap cair sebesar $10 \%$ dalam larutan garam dengan pencelupan selama 1 menit mampu menghambat pertumbuhan bakteri pembentuk histamin pada ikan tongkol.

\section{Kesimpulan}

Berdasarkan hasil dan pembahasan makan dapat disimpulkan antara lain :

1. Terjadi penuruan kadar senyawa fenol, karbonil dan asam asap cair setelah proses pemurnian

2. Kualitas kimia asap cair berbeda pada setiap konsentrasi dan kosentrasi asap cair $10 \%$ efektif untuk aplikasi pada pangan

\section{Daftar Pustaka}

AOAC. (1995). Official Methods of Analyses. 16 ed. Association of Official Analytical Chemists, Washington, D.C.

Darmadji, P. (1996). Aktivitas antibakteri asap cair yang diproduksi dari berbagai macam limbah pertanian. Agritech, $16: 19-22$.

Darmadji, P. dan H. Triyudiana. (2006). Proses pemurnian asap cair dan simulasi akumulasi kadar benzo(a)piren pada proses perendaman ikan. Agritech, 26 : 94-103. 
Darmadji, P., H. A. Oramahi, Haryadi, dan R. Armunanto. (2000). Optimasi produksi dan sifat fungsional asap kayu karet. Agritech, 20 : 147-155.

Darmadji, P., Supriyadi, dan C. Hidayat. (1999). Produksi asap rempah cair dari limbah padat rempah dengan cara pirolisis. Agritech, $19: 11-15$.

Estrada M. R., E. A. E. Boyle, and J. L. Marsden. (1998). Liquid smoke effects on Escherichia coli $\mathrm{O}$ 157: $\mathrm{H} 7$ and its antioxidant properties in beef products. J. Food Sci., $63: 159-153$.

Girard, J.P. (1992). Smoking in Technology of Meat and Meat Product. Ellis Horwood, New York.

Guillen, M. D. and M. L. Ibargoitia. (1999). Influence of the moisture content on the composition of the liquid smoke produced in the pyrolysis process of Fagus sylvatica L. wood. J. Agric. Food Chem., 47 : 4126-4136.

Indah Rodianawati. (2012). Komposisi Kimia Asap Cair Tempurung Biji Nyamplung (Calophyllum inophyllum Linn). Seminar Nasional Inovasi Teknologi Proses dan Produk Berbasis Sumber Daya Alam Indonesia dan Pelatihan Keselamatan Industri Kimia. Universitas Diponegoro, Semarang.

Kadir, S., P. Darmadji, C. Hidayat, dan Supriyadi. (2010). Fraksinasi dan indentifkasi senyawa volatil pada asap cair tempurung kelapa hibrida. Agritech, 30 : 57-67.

Kusharyati, D.F. (1998). Daya Hambat Asap Cair Tempurung Kelapa terhadap Pertumbuhan Bakteri Pembentuk Histamin pada Ikan Tongkol (Euthynus alleteratus). Tesis S2. Fakultas Pertanian Univeritas Gadjah Mada. Yogyakarta.

Luck, E. and M. Jager. (1995). Antimicrobial Food Additivies ; Characteristics, Uses, Effect. $2^{\text {nd }}$ Revised and Enlarged. Springer, Berlin.

Maga, J. A. (1987). Smoke in Food Processing. CRC. Press. Inc Boca Raton, Florida.

Pszczola, D.E. (1995). Tour highlights production and uses of smoke base flavors. Food Technol., 49 : 70-74.

Tranggono, Suhardi, B. Setiadji, Supranto, P. Darmadji, dan Sudarmanto. (1996). Identifikasi asap cair dari berbagai jenis kayu dan tempurung kelapa. Jurnal Ilmu dan Teknologi Pangan I (2) : 15-24.

Yusnaini. (2009). Kajian Awal Potensi Tempurung Kenari Sebagai Bahan Baku Produksi Asap Cair. Laporan Penelitian Mandri. Universitas Khairun, Ternate.

Yusnaini dan Indah Rodianawati. (2014). Produksi dan Kualitas Asap Cair dari Berbagai Jenis Bahan Baku. Senimar Nasional Penelitian dan Pengabdian Masyarakat 1 (4) : 253-260

Yusnaini, Soeparno, E. Suryanto dan R. Armunanto. (2012). Aktivitas antibakteri asap cair tempurung kenari. Cannarium 1 (14) : 111-119

Yusnaini, Soeparno, E. Suryanto dan R. Armunanto. (2012). Physical, chemical and sensory properties of kenari (canariun indicum L.) Shell liquid smoke-immersedbeef on different level of dilution: J. Indonesian Trop. Anim. Agric. 1 (37) : 27 33.

Yusnaini, Soeparno, Suryanto, E., dan Armunanto, R. (2013). Kajian Karakteristik Asap Cair Tempurung Kenari (Canarium inducim L.) sebagai pengambang Flavor. 
282 | Yusnaini, et al.

Disertasi. Program Pascasarjana, Fakultas Peternakan, Univeristas Gadjah Mada, Yogyakarta. 